\title{
Risk factors for delays in rail investments implemented in the Design \& Build contracts
}

\author{
Jan Kowalski ${ }^{1 *}$, Mieczysław Połoński ${ }^{1}$, Marzena Lendo - Siwicka ${ }^{1}$ \\ ${ }^{1}$ Warsaw University of Life Sciences (WULS - SGGW), Faculty of Civil and Environmental Engineering, \\ ul. Nowoursynowska 159, 02-787 Warsaw, Poland
}

\begin{abstract}
The article presents the results of nationwide surveys on the causes of delays during the implementation of rail investments in Poland, carried out in the Design \& Build formula for the design stage. The study did not examine typical causes of threats to general construction works, only those that result from the specifics of works at rail facilities. The survey was conducted with the participation of experts from various industries, representing all the key participants in the investment process. The selection of experts was limited to people who have extensive professional experience in implementing rail projects. Statistical analyzes were performed using the IBM SPSS Statistics 23 package. It was used to test $\chi 2$ and a one-way repeated measures ANOVA. The greatest threats to the deadlines for the implementation of rail investments in Poland, which were indicated by the respondents as the delay threats of a high importance are: negligence in the preparation of tender documents and problems with obtaining current maps for project purposes from rail geodesic centers. The research results can be helpful when planning future rail investments, calculating the necessary time reserves and increasing the reliability of the set dates of their completion.
\end{abstract}

\section{Introduction}

The implementation of each construction project, especially as complex and difficult as a rail facility is subject to a certain degree of uncertainty. Even if we have carefully prepared plans for the course of works of a given investment, we can never be sure that everything will proceed in accordance with the adopted assumptions. At each stage of the investment process, one must constantly monitor various risk factors that may arise during the implementation of an investment, so as to minimize their impact on a given contract. Depending on the stage of the investment process, the activities will be of a different nature. During planning, care should be taken to develop a schedule that is immune to disruptions (the so-called project schedule robustness). On the other hand, we must be prepared to minimize their negative effects when they occur. If a given project is not properly protected against threats, then the risk of their occurrence will increase as a result of abandonment of preventive measures, and the effects may turn out to be more serious than those anticipated [1, 2, 3, 4, 5, 6, 7]. In such cases, contract management personnel will be forced to react "ad hoc" to adverse events, without previously prepared scenarios for corrective actions and secured reserve resources.

Planning and execution of rail investments have their specificity, which results in a number of risk factors. They have a significant impact on extending the deadline for their completion and increase in the planned cost. This specificity does not apply to works carried out only in
Polish conditions, it also occurs in other countries $[8,9$, 10, 11, 12].

Large infrastructural investments are increasingly implemented in Poland on the basis of FIDIC conditions of contract, with two forms of these contracts being the most common. The first one concerns the formula, when the contracting party provides project documentation (the FIDIC Red Book). The second is the so-called Design \& Build (D\&B) formula based on the FIDIC Yellow Book. In this formula, the Investor's obligation is to have and attach to the tender procedure environmental permit, a possible declaration stating the right to use the property for construction purposes, a copy of the master map and the Functional-Utility Program (FUP). On the other hand, the Contractor's obligation is to develop project documentation, obtain the required building permit, and then carry out the work according to the prepared documentation. Since such a division of duties required by law transfers most of them to the Contractor, the D\&B formula is becoming increasingly common in Polish tender procedures. However, the consequence of the Contractor's greater involvement in the process of preparing and implementing the investment is to increase the number of risk factors that may occur during the work for which he is responsible and which should be taken into account when planning the contract in the D\&B formula. This applies in particular to the preparation, verification and receipt of project documentation and to obtain a building permit, i.e. a design stage.

In order to minimize the effects of unexpected, random threats during the preparation and implementation

*Corresponding author: jan_kowalski@ sggw.pl 
of future rail investments, the authors attempted to identify and list the most likely of them. The described research covered the scope of the Contractor's responsibilities related to the preparation of project documentation, who commences to perform the contract under the D\&B formula, and was aimed at determining those risk factors that may occur during the abovementioned works and have a significant impact on their planned schedule. The research was carried out with the participation of appropriately selected experts and statistical elaboration of data from a specially constructed questionnaire. The results presented in this paper are likely to help in the future identify risks in advance, prepare adequate remedies and, as a result, manage risk when planning and implementing Polish rail investments.

The science of risk is relatively new, and the terms applied are not always explicit, thus the authors indicate the definitions of the basic concepts that they use in this article.

- risk - the possibility of occurring through our actions, abandonment or forces of nature predictable at a given time, negative consequences of an undesirable random event, the effect and probability of which we are able to estimate,

- adverse event - is a measurable form of one or several risk factors, resulting in failure to achieve fully or not at all the intended purpose, and thus causing some loss,

- risk factor (threat) - a potential source of an adverse event that may or may not occur in the future.

\section{Methodology of research and development of survey results}

Rail investments as construction objects are very specific and the conditions for their implementation are not fully recognized. For this reason, the practical knowledge of people participating in the implementation of significant rail facilities is a very valuable source of information. This information was obtained by means of the expert questionnaire. The survey was conducted on the basis of a well-thought-out set of questions, which was sent to a selected group of respondents by e-mail. The survey was carried out nationally and related to investments implemented in the Design \& Build and Build formulas.

A necessary condition ensuring reliable research results was the appropriate selection of experts participating in them. It had to be people with a broad view of rail investments, taking into account the occurrence of adverse events and their consequences. The selection of experts was limited to persons who, on behalf of the Commissioning Party, Contractor, Designer or Contract Engineer as part of their professional duties, were responsible for the comprehensive management of rail contracts. The research sample consisted mainly of employees of construction companies performing independent technical functions in construction industry. The research group also included representatives of the institutional Investor (PKP PLK SA), which is the largest investor in rail investments in Poland. All respondents were Polish citizens. The questionnaire consisted of four parts (A to D). The first, filtration part of the form (Block
A) was aimed at checking whether a given person can be qualified to the expert group. The second and third parts of the questionnaire (Block B and C) were questions directly related to the purpose of the research, i.e. to identify and classify individual risk factors. Block B concerned the design phase, block $\mathrm{C}$ covered the implementation phase. Questions in these blocks were closed and their analysis was quantitative. Part four (Block D) included open questions.

Based on previous studies and literature analysis, the $\mathrm{B}$ and $\mathrm{C}$ blocks proposed a list of factors causing difficulties during the implementation of rail investments in Poland. Fifteen of them related to the design phase (Block B), eleven to the implementation phase (Block C). The questionnaire also took into account the possibility to supplement the proposed list of risk factors and obliged to answer open questions (Block D). The questionnaire was consulted with survey specialists and the target study was preceded by a pilot study that was conducted with 4 experts.

As a result, 112 copies of correctly completed questionnaires in the scope of Block B were obtained, as well as 85 copies from Block C. In tables 1-2, the basic data on the respondents were presented.

The experience of experts participating in the study, related to the wide range of investments implemented and their duties and powers, gives the basis for treating the results of the survey as representative and reliable in determining the scale of individual threats.

Table 1. Types of functions performed by respondents (party to a contract). Source: own study.

\begin{tabular}{|c|c|}
\hline $\begin{array}{c}\text { Percentage of } \\
\text { respondednts }\end{array}$ & $\begin{array}{c}\text { Respondednts' functions } \\
\text { ( party to a contract) }\end{array}$ \\
\hline $25 \%$ & Commissioning Party \\
\hline $37 \%$ & Contractor \\
\hline $7 \%$ & Contract Engineer Office \\
\hline $31 \%$ & Designer \\
\hline
\end{tabular}

Table 2. The experience of respondents in terms of completed investments (financial scale). Source: own study

\begin{tabular}{|c|c|}
\hline $\begin{array}{c}\text { Percentage of } \\
\text { respondents }\end{array}$ & $\begin{array}{c}\text { Internship of respondents } \\
\text { [million, PLN] }\end{array}$ \\
\hline $4 \%$ & below 10 \\
\hline $27 \%$ & 10 to 100 \\
\hline $69 \%$ & above 100 \\
\hline
\end{tabular}

The presented research was carried out in four stages. In the first stage, the study was designed from the substantive and technical side. The aim of the research was specified: diagnostic (what and why we study), and practical (to whom and what the research is dedicated). Next, a preliminary survey model was developed. After completing the pilot study and refining the survey form, the respondents were collected in the next stage of the study. The data was appropriately grouped into numerical sets and developed using the appropriate statistical models available in the IBM SPSS Statistics 23 package. 
It was used to perform $\chi^{2}$ tests and one-way repeated measures ANOVA which compares between groups variance to within groups variance. In a one-factor scheme (one-way analysis of variance), it was checked whether the type of event (independent variable) differentiates the level of weight of a given event (dependent variable). If a statistically significant result was obtained from the analysis of variance, post-hoc tests were performed to verify which specific events are assessed as more or less threatening to efficient implementation from others. When interpreting the results of calculations, it should be remembered that the smaller the significance of the $p$ value, the smaller the chance that the difference is accidental. The $\chi 2$ tests were carried out for the tested data on the qualitative scale. They allow to determine if there are stochastic relations between features. With the help of the Cramer V coefficient, the strength of the recorded compounds was determined, i.e., if $\mathrm{V}=0<0.3$ - weak, $\mathrm{V}=(0.3 \div 0.5)$ - moderate, $\mathrm{V}=(0.5$ $\div 0.7)$ - strong, $\mathrm{V}=(0.7 \div 0.9)$ - very strong, $\mathrm{V}>0.9$ almost full relation. The level of $\mathrm{p}<0.05$ was assumed as the level of statistical significance in the studies. The further part of the article discusses only the risk factors occurring during the implementation of rail contracts in the D\&B formula at the design stage and the interrelationship between the risk factors was not analyzed.

\section{Results}

\subsection{Analysis of the frequency of occurrence of specific events}

First, it was analyzed whether the incidence of specific events was similar or different. Therefore, the analysis was carried out using the $\chi 2$ test. A statistically significant result was obtained: $\chi 2(14)=218.9 ; p<0.001 ; \mathrm{V}=0.36$. This means that individual events in the opinion of experts occurred with different frequency. As it is clearly seen in Table 3, the most common events were weaknesses in the preparation of tender documents and problems with obtaining current maps for project purposes from rail geodesic centers. Both dangers occurred in about $90 \%$ of the analyzed cases. The second group of relatively frequent risk factors were events with a probability of occurrence within the limits of $80-90 \%$. These include: improperly estimated time of preparation of project documentation by the Commissioning Party, the need to make exceptions to the guidelines from the tender stage and problems with agreeing the project documentation with external Stakeholders. On the other hand, there were few problems with having a complete set of legal documents regarding the area planned for the investment and delay in obtaining decisions on building permits due to the Commissioning Party's fault, which occurred in less than $50 \%$ of the analyzed cases The strength of the recorded relation, in general for all fifteen analyzed events, was moderately large, which is indicated by the Cramer V coefficient value $\mathrm{V}=0.36$.

Table 3. Prevalence of specific events in questionnaires, where: $\mathrm{N}$ - number of questionnaires. Source: own study

\begin{tabular}{|c|c|c|c|}
\hline \multirow{2}{*}{\multicolumn{2}{|c|}{ Description of examined threats }} & \multicolumn{2}{|c|}{ Occurence } \\
\hline & & \multirow{2}{*}{$\begin{array}{c}\text { No } \\
11\end{array}$} & \multirow{2}{*}{$\begin{array}{l}\text { Yes } \\
101\end{array}$} \\
\hline Pro & $\mathrm{N}$ & & \\
\hline & 0 & 9.8 & 90.2 \\
\hline \multirow{2}{*}{$\begin{array}{l}\text { Improperly estimated deadline for the } \\
\text { development of project } \\
\text { documentation by the } \\
\text { Commissioning party. }\end{array}$} & $\mathrm{N}$ & 21 & 91 \\
\hline & $\%$ & 18.8 & 81.3 \\
\hline \multirow{2}{*}{$\begin{array}{l}\text { Too many external institutions } \\
\text { involved in the investment process. }\end{array}$} & $\mathrm{N}$ & 26 & 86 \\
\hline & 0 & 23.2 & 76.8 \\
\hline \multirow{2}{*}{$\begin{array}{l}\text { The necessity to make exceptions to } \\
\text { the guidelines from the tender stage. }\end{array}$} & $\mathrm{N}$ & 15 & 97 \\
\hline & $\%$ & 13.4 & 86.6 \\
\hline \multirow{2}{*}{$\begin{array}{l}\text { Errors in the conceptual design } \\
\text { documentation from the tender stage. }\end{array}$} & $\mathrm{N}$ & 26 & 86 \\
\hline & 8 & 23.2 & 76.8 \\
\hline \multirow{2}{*}{$\begin{array}{l}\text { Problems with obtaining current } \\
\text { maps for project purposes from rail } \\
\text { geodesic centers. }\end{array}$} & $\mathrm{N}$ & 12 & 100 \\
\hline & $\%$ & 10.7 & 89.3 \\
\hline \multirow{2}{*}{$\begin{array}{l}\text { Problems with reconciliation of } \\
\text { project documentation with external } \\
\text { Stakeholders. }\end{array}$} & $\mathrm{N}$ & 16 & 96 \\
\hline & $\%$ & 14.3 & 85.7 \\
\hline \multirow{2}{*}{$\begin{array}{l}\text { Problems with reconciliation of } \\
\text { project documentation with internal } \\
\text { companies from the PKP group }\end{array}$} & $\mathrm{N}$ & 24 & 88 \\
\hline & $\%$ & 21.4 & 78.6 \\
\hline \multirow{2}{*}{$\begin{array}{l}\text { Problems with reconciliation of } \\
\text { project documentation with the } \\
\text { owners of technical infrastructure on } \\
\text { the premises of PKP. }\end{array}$} & $\mathrm{N}$ & 24 & 88 \\
\hline & $\%$ & 21.4 & 78.6 \\
\hline \multirow{2}{*}{$\begin{array}{l}\text { Long-term procedures for agreeing } \\
\text { project documentation within PKP } \\
\text { PLK. }\end{array}$} & $\mathrm{N}$ & 26 & 86 \\
\hline & 0 & 23.2 & 76.8 \\
\hline \multirow{2}{*}{$\begin{array}{l}\text { Problems with the acceptance of } \\
\text { project documentation by the } \\
\text { Contract Engineer. }\end{array}$} & $\mathrm{N}$ & 49 & 63 \\
\hline & 0 & 43.8 & 56.3 \\
\hline \multirow{2}{*}{$\begin{array}{l}\text { Did the Commissioning Party have a } \\
\text { set of legal documents regarding the } \\
\text { area planned for the investment } \\
\text { within the deadline? }\end{array}$} & $\mathrm{N}$ & 71 & 41 \\
\hline & $\%$ & 63.4 & 36.6 \\
\hline \multirow{2}{*}{$\begin{array}{l}\text { Was obtaining the decision on } \\
\text { building permits delayed due to the } \\
\text { fault of the Commissioning Party? }\end{array}$} & $\mathrm{N}$ & 61 & 51 \\
\hline & 0 & 54.5 & 45.5 \\
\hline \multirow{2}{*}{$\begin{array}{l}\text { Was the decision on building permits } \\
\text { delayed due to the Designer's fault? }\end{array}$} & $\mathrm{N}$ & 55 & 57 \\
\hline & 0 & 49.1 & 50.9 \\
\hline \multirow{2}{*}{$\begin{array}{l}\text { Was the decision on building permits } \\
\text { delayed due to the fault of the } \\
\text { external unit, e.g. additional } \\
\text { agreements? }\end{array}$} & $\mathrm{N}$ & 40 & 72 \\
\hline & $\%$ & 35.7 & 64.3 \\
\hline
\end{tabular}




\subsection{Analysis of delays due to specific events}

Table 4. Frequency of delays resulting from the analyzed threats, where: $\mathrm{N}$ - number of surveys. Source: own study.

\begin{tabular}{|c|c|c|c|}
\hline \multicolumn{2}{|l|}{ Description of examined $t$} & \multicolumn{2}{|c|}{$\begin{array}{c}\text { Occurence of } \\
\text { delay }\end{array}$} \\
\hline & & \multirow{2}{*}{$\begin{array}{c}\text { No } \\
18\end{array}$} & \multirow{2}{*}{ Yes } \\
\hline & $\mathrm{N}$ & & \\
\hline & $\%$ & 16.1 & 83.9 \\
\hline \multirow{2}{*}{$\begin{array}{l}\text { Improperly estimated deadline for the } \\
\text { development of project } \\
\text { documentation by the } \\
\text { Commissioning party. }\end{array}$} & $\mathrm{N}$ & 38 & 74 \\
\hline & $\%$ & 33.9 & 66.1 \\
\hline \multirow{2}{*}{$\begin{array}{l}\text { Too many external institutions } \\
\text { involved in the investment process. }\end{array}$} & $\mathrm{N}$ & 30 & 82 \\
\hline & $\%$ & 26.8 & 73.2 \\
\hline \multirow{2}{*}{$\begin{array}{l}\text { The necessity to make exceptions to } \\
\text { the guidelines from the tender stage. }\end{array}$} & & 31 & 81 \\
\hline & $\%$ & 27.7 & 72.3 \\
\hline & $\mathrm{N}$ & 37 & 75 \\
\hline & $\%$ & 33.0 & 67.0 \\
\hline \multirow{2}{*}{$\begin{array}{l}\text { Problems with obtaining current } \\
\text { maps for project purposes from rail } \\
\text { geodesic centers. }\end{array}$} & $\mathrm{N}$ & 21 & 91 \\
\hline & 0 & 18.8 & 81.3 \\
\hline \multirow{2}{*}{$\begin{array}{l}\text { Problems with reconciliation of } \\
\text { project documentation with external } \\
\text { Stakeholders. }\end{array}$} & $\mathrm{N}$ & 24 & 88 \\
\hline & 0 & 21.4 & 78.6 \\
\hline \multirow{2}{*}{$\begin{array}{l}\text { Problems with reconciliation of } \\
\text { project documentation with internal } \\
\text { companies from the PKP group. }\end{array}$} & $\mathrm{N}$ & 35 & 77 \\
\hline & 0 & 31.3 & 68.8 \\
\hline \multirow{2}{*}{$\begin{array}{l}\text { Problems with reconciliation of } \\
\text { project documentation with the } \\
\text { owners of technical infrastructure on } \\
\text { the premises of PKP. }\end{array}$} & $\mathrm{N}$ & 39 & 73 \\
\hline & $\%$ & 34.8 & 65.2 \\
\hline \multirow{2}{*}{$\begin{array}{l}\text { Long-term procedures for agreeing } \\
\text { project documentation within PKP } \\
\text { PLK. }\end{array}$} & $\mathrm{N}$ & 28 & 84 \\
\hline & & 25.0 & 75.0 \\
\hline \multirow{2}{*}{$\begin{array}{l}\text { Problems with the acceptance of } \\
\text { project documentation by the } \\
\text { Contract Engineer. }\end{array}$} & $\mathrm{N}$ & 60 & 52 \\
\hline & $\%$ & 53 & 46.4 \\
\hline \multirow{2}{*}{$\begin{array}{l}\text { Did the Commissioning Party have a } \\
\text { set of legal documents regarding the } \\
\text { area planned for the investment } \\
\text { within the deadline? }\end{array}$} & $\mathrm{N}$ & 37 & 75 \\
\hline & $\%$ & 33.0 & 67.0 \\
\hline \multirow{2}{*}{$\begin{array}{l}\text { Was obtaining the decision on } \\
\text { building permits delayed due to the } \\
\text { fault of the Commissioning Party? }\end{array}$} & $\mathrm{N}$ & 6 & 48 \\
\hline & 0 & 57.1 & 42.9 \\
\hline \multirow{2}{*}{$\begin{array}{l}\text { Was the decision on building permits } \\
\text { delayed due to the Designer's fault? }\end{array}$} & 10 & 58 & 54 \\
\hline & & 51.8 & 48.2 \\
\hline \multirow{2}{*}{$\begin{array}{l}\text { Was the decision on building permits } \\
\text { delayed due to the fault of the } \\
\text { external unit, e.g. additional } \\
\text { agreements? }\end{array}$} & $\mathrm{N}$ & 4 & 71 \\
\hline & $\%$ & 36.6 & 63.4 \\
\hline
\end{tabular}

Knowing the frequency of occurrence of the examined threats, it was further investigated whether specific events caused delays with similar or different frequency. For this purpose, another analysis was performed using the $\chi 2$ test. In this case, a statistically significant result was also recorded: $\chi 2(14)=107.33 ; p<0.001 ; \mathrm{V}=0.25$.

The results presented in Table 4 mean that delays due to individual events occurred at different rates. In addition, it can be seen that again, the most frequently indicated events causing delays were negligence in the preparation of tender documents and problems with obtaining current maps for design purposes. They occurred in over $80 \%$ of the analyzed cases. Relatively often, delays occurred also due to: too many external institutions involved in the investment process, the need to make exceptions to the guidelines from the tender stage, problems with agreeing project documentation with external stakeholders (Road Managers, Offices, etc.), long-term procedures for agreeing project documentation inside PKP PLK. On the other hand, the least frequent delays were caused by prolonged obtaining of decisions on building permits due to the fault of the Commissioning Party or Designer and problems with the acceptance of the project documentation by the Contract Engineer. These delays appeared in less than $50 \%$ of the cases analyzed. However, the strength of the recorded relation for all fifteen types of events was low $(\mathrm{V}=0.25)$.

\subsection{Analysis of importance of specific problems}

In order to verify whether the importance of specific threats is similar or different, a one-way repeated measures ANOVA was performed. As a consequence of the conducted tests, the statistically significant result was again noted: $\mathrm{F}(14.17)=7.79, p<0.001, \eta 2=0.06$. Such a result allowed to perform the analysis by post-hoc Sidak test. In this analysis, comparisons of each event with each were made. Statistically significant key differences are indicated below:

- negligence in preparing the tender documents was assessed as more important than: too many external institutions involved in the investment process $(p=$ 0.024); problems with reconciliation of project documentation with the owners of technical infrastructure $(p=0.023)$; problems with the acceptance of project documentation by the Contract Engineer $(p<0.001)$; delay in obtaining decisions on building permits due to the Commissioning Party's fault $(p<0.001)$ and Designer's fault $(p=0.006)$

- improper estimation of the date of preparation of project documentation by the Commissioning Party was significantly less important than problems with obtaining current maps for project purposes from rail surveying centers $(p=0.046)$, and more important than problems with acceptance of project documentation by the Contract Engineer $(p=0.002)$ and delays in obtaining decisions on building permits due to the fault of the Commissioning Party $(p=0.043)$

- too many external institutions involved in the investment process were less important than problems with obtaining current maps for project purposes from rail geodesic centers $(p<0.001)$;

*Corresponding author: jan_kowalski@sggw.pl 
- the need to make derogations from the guidelines from the tender stage was less important than problems with obtaining current maps for project purposes from rail surveying centers $(p=0.002)$ and more important than problems with acceptance of project documentation by the Contract Engineer $(p=0.050)$;

- errors in the conceptual design documentation from the tender stage were less important than problems with obtaining current maps for project purposes from rail geodesic centers $(p<0.001)$;

- problems with obtaining current maps for project purposes from rail geodesic centers were more important than: problems with agreeing project documentation with external Stakeholders $(p=0.001)$, problems with reconciliation of project documentation with owners of localized technical infrastructure $(p<0.001)$, problems with acceptance project documentation by the Contract Engineer $(p<0.001)$, the Commissioning Party has, within the set deadline, legal documents regarding the area planned for the investment $(p<0.001)$, delays in obtaining decisions on building permits due to the fault of the Commissioning Party $(p<0.001)$ and Designer $(p<0.001)$;

- problems with agreeing project documentation with external Stakeholders were more important than problems with the acceptance of project documentation by the Contract Engineer $(p<0.001)$ and delays in obtaining decisions on building permits due to the fault of the Commissioning Party $(\mathrm{p}=0.001)$;

- long-lasting procedures for agreeing project documentation within PKP PLK were more important than problems with acceptance of project documentation by the Contract Engineer $(p=0.001)$ and delays in obtaining decisions on building permits due to the fault of the Commissioning Party $(p=0.016)$;

- problems with the acceptance of project documentation by the Contract Engineer were less important than delays in obtaining decisions on building permits due to the external fault $(p=0.002)$;

- delay in obtaining decisions for building permits due to the fault of the Commissioning Party was less important than delays in obtaining decisions on building permits due to fault of the external unit $(p=0.034)$.

\section{Conclusions and summary}

The article presents the results of extensive research on threats that occurred during the preparation and implementation of rail investments in Poland and had an impact on extending the planned deadline for their completion. The research concerned rail facilities implemented in the D\&B formula. In the presented part of the research only those threats that may occur at the design stage, and result from the specifics of this type of investment, were taken into account.

The study was conducted on a large group of respondents with knowledge and experience relevant to the results. The results presented in this report, according to the authors, may contribute to reducing the impact of the most common threats and the importance of more reliable planning for the implementation of future rail investments in Poland.

Table 5. Importance of defined events where: $\mathrm{M}$ - importance of a problem, SD - standard deviation. Source: own study.

\begin{tabular}{|c|c|c|}
\hline Description of examined threats & $M$ & $S D$ \\
\hline $\begin{array}{l}\text { (a) Procedural defects in preparation of } \\
\text { tender documents. }\end{array}$ & 5.90 & 3.18 \\
\hline $\begin{array}{l}\text { (b) Improperly estimated deadline for the } \\
\text { development of project documentation by } \\
\text { the Commissioning party. }\end{array}$ & 5.00 & 3.75 \\
\hline $\begin{array}{l}\text { (c) Too many external institutions involved } \\
\text { in the investment process. }\end{array}$ & 4.35 & 2.87 \\
\hline $\begin{array}{l}\text { (d) The necessity to make exceptions to the } \\
\text { guidelines from the tender stage. }\end{array}$ & 4.68 & 2,76 \\
\hline $\begin{array}{l}\text { (e) Errors in the conceptual design } \\
\text { documentation from the tender stage. }\end{array}$ & 4.47 & 3.18 \\
\hline $\begin{array}{l}\text { (f) Problems with obtaining current maps } \\
\text { for project purposes from rail geodesic } \\
\text { centers. }\end{array}$ & 6.48 & 3.28 \\
\hline $\begin{array}{l}\text { (g) Problems with reconciliation of project } \\
\text { documentation with external Stakeholders. }\end{array}$ & 5.36 & 2.86 \\
\hline $\begin{array}{l}\text { (h) Problems with reconciliation of project } \\
\text { documentation with internal companies } \\
\text { from the PKP group. }\end{array}$ & 4.60 & 2.85 \\
\hline $\begin{array}{l}\text { (i) Problems with reconciliation of project } \\
\text { documentation with the owners of technical } \\
\text { infrastructure on the premises of PKP. }\end{array}$ & 4.34 & 2.73 \\
\hline $\begin{array}{l}\text { (j) Long-term procedures for agreeing } \\
\text { project documentation within PKP PLK. }\end{array}$ & 5.11 & 2.96 \\
\hline $\begin{array}{l}\text { (k) Problems with the acceptance of project } \\
\text { documentation by the Contract Engineer. }\end{array}$ & 3.21 & 2.94 \\
\hline $\begin{array}{l}\text { (1) Did the Commissioning Party have a set } \\
\text { of legal documents regarding the area } \\
\text { planned for the investment within the } \\
\text { deadline? }\end{array}$ & 4.46 & 3.10 \\
\hline $\begin{array}{l}\text { (m) Was obtaining the decision on building } \\
\text { permits delayed due to the fault of the } \\
\text { Commissioning Party? }\end{array}$ & 3.51 & 3.35 \\
\hline $\begin{array}{l}\text { (n) Was the decision on building permits } \\
\text { delayed due to the Designer's fault? }\end{array}$ & 4.21 & 3.63 \\
\hline $\begin{array}{l}\text { (o) Was the decision on building permits } \\
\text { delayed due to the fault of the external unit, } \\
\text { e.g. additional agreements? }\end{array}$ & 5.03 & 3.62 \\
\hline
\end{tabular}

The analysis presented in the article indicates unequivocally that the assessed threats are statistically significant and thus they can have a significant impact on the course of rail investments. The most important threats to the deadlines for the implementation of these facilities in Poland, which were identified by the respondents as threats of a high severity are: negligence in the preparation of tender documents and problems with obtaining current maps for project purposes from rail geodesic centers.

As the most rare threats, the following were indicated: problems with having a complete set of legal documents 
regarding access to the premises intended for investment, delay in obtaining decisions on building permits due to the fault of the Commissioning Party or Designer, and problems with acceptance of project documentation by the Contract Engineer.

Due to the high assessment of the importance of the analysed threats, during the planning of future rail investments, particular attention should be paid to the risks that were determined with the average importance of the problem $\mathrm{M}$ above 4.95 (Table 5, Fig.1.) during the study. These threats when scheduling future rail investments should be secured with appropriate time-cost reserves (buffers).

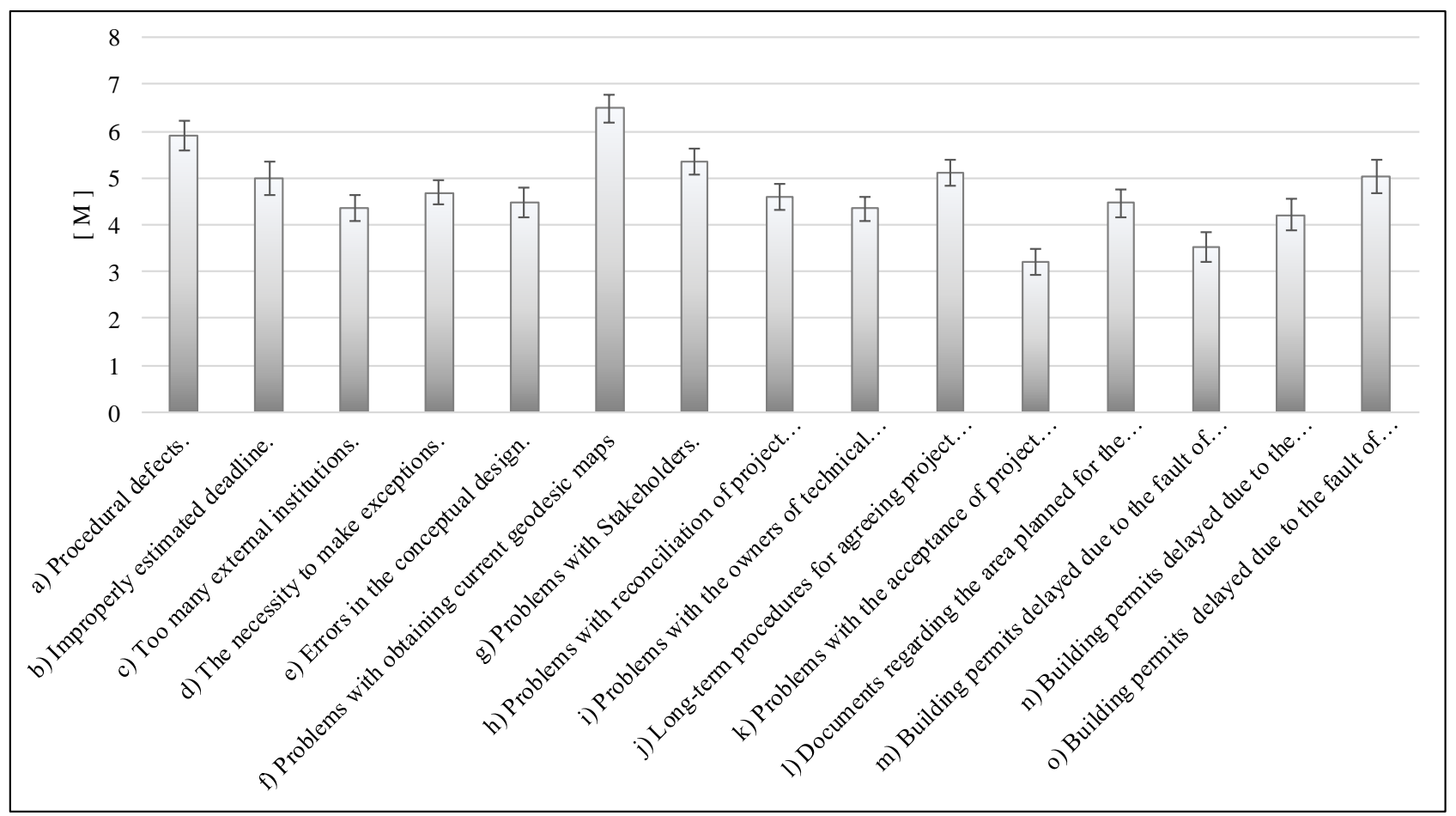

Fig. 1. Importance of defined events. Standard deviation. Source: own study

In order to streamline the identification of problems related to the risk of Polish rail investments, the authors plan further research in this area. Investments implemented in the Build formula and the impact of threats on the increase of the planned costs will be subject to the analysis.

\section{References}

1. M. Połoński, J. Kowalski, Materiały budowlane, 6: 162-163, (2016)

2. M. Połoński, J. Kowalski, Technical transactions, 5: 47-55, (2017)

3. M. Lendo-Siwicka, K. Pawluk, M. Połoński, A. Goszczyńska, Materiaty Budowlane, 6: 154-155, (2016)

4. D. Skorupka, M. Kowacka, Archives of Civil Engineering, 62(2), 183-190, (2016)

5. Dziadosz, A. Tomczyk, O. Kapliński, Procedia Engineering, 122, 120-128, (2015)

6. B. Gładysz, D. Skorupka,D. Kuchta, A. Duchaczek, Procedia Computer Science, 64, 24-31, (2015)

7. O. Kapliński, Procedia Engineering, 57, 533-539, (2013)
8. L. Wang, Y. LI., E. Wang, International Conference on Risk and Engineering Management, Procedia Engineering, 1: 174-180, (2011)

9. S. Ploywarin, Y. Song, International Journal of Management Sciences and Business Research 3: 2226-8235, (2014)

10. J. Tang, Y. Wang, International Conference on Information Management, Innovation Management and Industrial Engineering: 237-239, (2013)

11. D. Sunduck. SUH, Ph.D., P.E. IATSS Research, 24(2): 53-63, (2000).

12. Q. LI, R. LIU, J. ZHANG, Q. SUN, International Symposium on Safety Science and Technology, Procedia Engineering: 84, 195-203, (2014) 